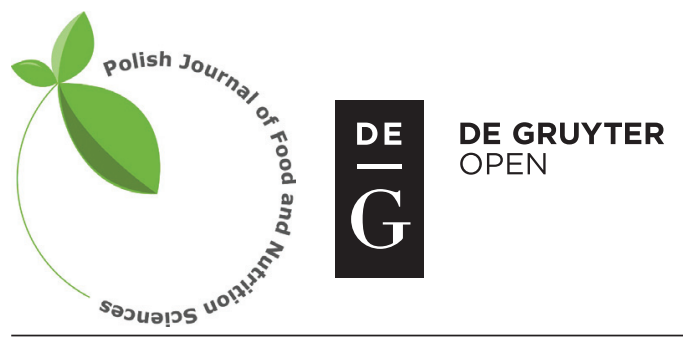

Pol. J. Food Nutr. Sci., 2016, Vol. 66, No. 2, pp. 99-107 DOI: $10.1515 /$ pjfns-2015-0041

Original article

Section: Food Technology

\title{
Identification of Predominant Lactic Acid Bacteria and Yeasts of Turkish Sourdoughs and Selection of Starter Cultures for Liquid Sourdough Production Using Different Flours and Dough Yields
}

\author{
Gülten Yağmur ${ }^{1}$, Hasan Tanguler ${ }^{1,4}$, Sezgi Leventdurur ${ }^{1}$, Simel Bağder Elmact ${ }^{2}$, Emel Ünal \\ Turhan $^{1,5}$, Nicola Francesca ${ }^{3}$, Luca Settanni ${ }^{3}$, Giancarlo Moschetti ${ }^{3}$, Hüseyin Erten ${ }^{1, *}$ \\ ${ }^{1}$ Department of Food Engineering, Faculty of Agriculture, Cukurova University, 01330, Adana, Turkey \\ ${ }^{2}$ Department of Food Engineering, Faculty of Engineering, Ankara University, 06110 Ankara, Turkey \\ ${ }^{3}$ Dipartimento Scienze Agrarie e Forestali, Università degli Studi di Palermo, Viale delle Scienze 4, 90128 Palermo, Italy \\ ${ }^{4}$ Present address: Department of Food Engineering, Faculty of Engineering, Nigde University, \\ Merkez Yerleşke 51245 Nigde, Turkey \\ ${ }^{5}$ Present address: Kadirli School of Applied Sciences, Osmaniye Korkut Ata University, Osmaniye, Turkey
}

Key words: Turkish sourdoughs, lactic acid bacteria, yeasts, liquid sourdough

Eight samples of mature sourdough were collected from five provinces of Turkey. Lactic acid bacteria and yeasts were isolated and identified and used in different combinations to produce liquid sourdoughs. Microbiological and physicochemical characteristics of the experimental sourdoughs made with different flour types and dough yields were studied. The main lactic acid bacteria species identified were Lactobacillus $(L$.) sanfranciscensis, Pediococcus pentosaceus, L. plantarum, L. namurencis, L. rossiae, Leuconostoc mesenteroides and L. zymae. L. spicheri, L. paralimentarius, L. mindensis, L. farciminis, L. acetotolerans, L. casei, Enterococcus faecium and Enterococcus durans were also found in sourdoughs at subdominant levels. Among yeasts, mainly Saccharomyces cerevisiae, but also Pichia guiliermondii and Torulaspora delbrueckii were the predominant species of yeasts identified in sourdoughs.

Lactic acid bacteria and yeasts of liquid sourdoughs after fermentation were in the range of 9.61-9.89 log cfu/g and 6.55-7.36 log cfu/g, respectively. Various chemical parameters such as $\mathrm{pH}$, total titratable acidity, lactic and acetic acids, ethanol and sugars were determined for liquid sourdoughs. Acidification and metabolite contents of these products were different, depending on the starter culture, flour type and dough yield. Total titratable acidity was more pronounced in the sourdoughs produced with whole wheat flour $(14.08 \mathrm{~mL} \mathrm{NaOH})$ and rye flour $(13.56 \mathrm{~mL} \mathrm{NaOH})$, dough yield 250 $(13.93 \mathrm{~mL} \mathrm{NaOH})$ and control sample $(13.12 \mathrm{~mL} \mathrm{NaOH})$ which were produced without inoculum.

\section{INTRODUCTION}

Bread baking using sourdough dates back to ancient times [Meroth et al., 2003]. Sourdough is a starter culture made with a mixture of mainly wheat or rye flour and water and is fermented spontaneously by the action of lactic acid bacteria and yeasts. As an intermediate fermented product, it is used to produce a variety of bakery products such as sourdough bread, crackers, snacks, pizza and sweet baked goods [Valmorri et al., 2010; Minervini et al., 2014]. Sourdough plays an important role by improving the technological, nutritional, sensory properties and shelf-life of traditional breads and sweet leavened bakery products [Corsetti \& Settanni, 2007; Scheirlinck et al., 2009; Vogelmann et al., 2009; Ravyts \& De Vuyst, 2011].

Sourdoughs, based on the technology applied, can be mainly classified into three protocols [Gobbetti et al., 2005; Corsetti \& Settanni, 2007; Minervini et al., 2012b, 2014]:

\footnotetext{
* Corresponding Author: Tel.: + 90322 3386084/2180;

Fax: + 90322 3386614; E-mail address: herten@cu.edu.tr
}

namely type I, type II and type III. Type I is the traditional process that is characterized by continuous, daily refreshment (back-slopping) to keep the sourdough flora in an active state. Type II refers to liquid sourdoughs, whereas type III is the dried form of the liquid sourdoughs. Both are industrially manufactured and are commonly used by the bakeries. Type II and Type III sourdough require the addition of bakers' yeast, Saccharomyces cerevisiae, for leaving. However, other traditional protocols are also applied in artisanal and industrial bakeries.

At the beginning of first fermentation, sourdough microbiota consists of lactic acid bacteria, Gram-positive (e.g. Bacillus sp.) and Gram-negative (e.g. Pseudomonas sp.) aerobic bacteria, Enterobacteriaceae, yeasts and moulds with less than $5 \mathrm{log}$ $\mathrm{cfu} / \mathrm{g}$ for each group. After daily continuous refreshment with the addition of flour and water, lactic acid bacteria and yeasts dominate the sourdough microbiota at the numbers ranging from 6-9 $\log \mathrm{cfu} / \mathrm{g}$ and from 5-8 $\log \mathrm{cfu} / \mathrm{g}$, respectively [Minervini et al., 2014]. The ratio between yeasts and lactic acid bacteria in sourdough is generally 1:100 [Rollàn et al., 2010; Banu \& Aprodu, 2012]. These lactic acid bacteria and yeasts 
originate from raw materials, mainly flour [Alfonzo et al., 2013] and other ingredients, and bakery equipment and environment [Catzeddu et al., 2006; Zannini et al., 2009].

More than 50 species of lactic acid bacteria which are mostly species of the homofermentative and heterofermentative Lactobacillus (L.) (almost 30 species) and to a lesser extent the species of the genera Leuconostoc, Pediococcus, Weissella, Lactoccoccus, Enterococcus and Streptococcus are found in sourdoughs. Both homofermentative and heterofermentative lactic acid bacteria contribute to dough acidification [Corsetti \& Settanni, 2007; Valmorri et al., 2008; Vera et al., 2009; Minervini et al., 2012a; Lattanzi et al., 2013]. In general, L. sanfranciscensis, L. paralimentarius, L. rossiae, $L$. plantarum and $L$. brevis are frequently dominating species in sourdoughs [Gobbetti, 1998; De Vuyst et al., 2009; Zannini et al., 2009; Minervini et al., 2012a]. In addition, other strains of lactic acid bacteria including $L$. divergens, L. amylophilus, L. sake, L. acetotolerans, L. fermentum, L. pontis, L. reuteri, Pediococcus pentosaceus, Pediococcus acidilactici and Tetragenococcus halophilus (formerly Pediococcus halophilus) are also found in sourdoughs [Salin-ur-Rehman et al., 2006; Minervini et al., 2012a].

Yeasts form carbon dioxide, therefore leading to the leavening process. More than 20 different species of yeasts have been reported to be isolated from sourdoughs. The most frequently isolated yeasts are Saccharomyces cerevisiae, Candida milleri (Synonym Candida humilis), Candida krusei, Kazachstania exigua (synonym Saccharomyces exiguus), Pichia norvegensis, Torulaspora delbrueckii and Wickerhamomyces anomalus (formerly Pichia anomala) [Valmorri et al., 2008; Minervini et al., 2012a].

The ecological factors influence the microbial ecology of the sourdough fermentation. During continuous propagation of sourdough, the impact of some parameters such as dough yield, amount and composition of the starter, number of propagation steps, fermentation time [Meroth et al., 2003] process technology, production environment and many other factors cause the selection of a characteristic microbiota consisting of lactic acid bacteria and yeasts [Scheirlinck et al., 2007].

Although there are various studies on the flora of Turkish sourdoughs using phenotypic methods [Özcangaz, 2000; Menteş et al., 2004; Gül et al., 2005; Şimşek et al., 2006], information concerning sourdough microbiota of different regions of Turkey is quite limited. Various traditional bakeries in different cities use spontaneously fermented sourdoughs, produced mainly from wheat flour and are refreshed with addition of flour and water at regular intervals to keep the microorganisms metabolically active.

Carnevali et al. [2007] showed that the industrial application of liquid sourdough can offer several advantages like easier control of the acidity, the production of various aromatic compounds, easier management reproducibility during operative conditions, the creation of great variety of bakery products distinguishable in flavour, texture and health benefits. The bakers can have products with higher or lower acidity according to the texture and flavour they need using liquid sourdough which is a natural and flexible technology. It can also be adapted easily to the production line in industrial bread production.
This study firstly aimed to determine the dominant lactic acid bacteria and yeast microbiota using molecular methods in Turkish sourdoughs which are used for the production of traditional sourdough breads in different provinces of Turkey. Secondly, it was aimed to understand the effect of different parameters like starter culture, flour type and dough yield on the production of liquid sourdough.

\section{MATERIAL AND METHODS}

\section{Sourdoughs}

Eight samples of mature sourdough used for the manufacture of traditional sourdough breads were collected from traditional bakeries from several provinces of Turkey. Sourdough A was obtained from Mevlana Taş Firnn Bakery in Trabzon, sourdough B from Sağlam Ekmek Bakery in Trabzon, sourdough C from ISP Bakery in Isparta, sourdough D from Somuncu Baba Ekmek Bakery 1 in Kütahya, sourdough E from Somuncu Baba Ekmek Bakery 2 in Kütahya, sourdough $\mathrm{F}$ from Untad Bakery in Ankara, sourdough $\mathrm{G}$ from Merve Unlu Mamülleri Bakery in Ankara, and sourdough H from Adana. All samples were aseptically taken into sterilised jar at the end of the final back-slopping and transferred to laboratory at $4^{\circ} \mathrm{C}$ for analyses. All sourdoughs were made with Triticum aestivum flour according to the manufacturers. The ingredients used for preparing the sourdoughs were flour, sourdough coming from a previous fermentation, and tap water. All sourdoughs were analyzed in duplicate.

\section{Enumeration and isolation of microorganisms}

Decimal dilutions of sourdough samples $(25 \mathrm{~g})$ were prepared in sterile physiological solution $(225 \mathrm{~mL})$. Total mesophilic aerobic bacteria were counted on Plate Count Agar after incubation at $30^{\circ} \mathrm{C}$ for 3 days. Lactic acid bacteria were estimated and isolated by plating serial decimal dilutions on modified MRS (produced with maltose and fresh yeast extract at a final concentrations of 1 and 10\%, respectively, $\mathrm{pH}$ : 5.6) agar medium supplemented with $50 \mu \mathrm{g} / \mathrm{L}$ of cycloheximide for prevention of the growth of yeasts and moulds. The plates were incubated at $30^{\circ} \mathrm{C}$ for 3 days in jars made anaerobic with GasPaks (Anaerocult, Merck) for colony development. After enumeration based on their morphology onto plates, various colony types (at least 10 colonies) were randomly selected from agar plates containing 100 to 300 colonies. All isolates were tested for Gram reaction and catalase activity, rod or cocci. Single colonies were purified by streaking on fresh agar medium and incubated as above [Settanni et al., 2011]. The isolates were maintained in $20 \%(\mathrm{v} / \mathrm{v})$ glycerol at $-20^{\circ} \mathrm{C}$ until further experiments. Yeasts and moulds were determined on Potato Dextrose Agar supplemented with $50 \mu \mathrm{g} / \mathrm{L}$ of oxotetracycline to prevent bacterial growth. Plates were incubated for $4-5$ days at $25^{\circ} \mathrm{C}$ and, then yeast colonies were counted. Non-Saccharomyces yeasts were counted on L-lysine agar. The purified yeast colonies were maintained in $20 \%(\mathrm{v} / \mathrm{v})$ glycerol at $-20^{\circ} \mathrm{C}$ for further experiments.

\section{Genotypic identification of lactic acid bacteria}

Genomic DNA of lactic acid bacteria was isolated according to De Los Reyes-Gavilán et al. [1992] with slight 
modification. Briefly, $5 \mathrm{~mL}$ of overnight grown culture in MRS broth were harvested by centrifugation $(13,000 \mathrm{rpm}$ for $5 \mathrm{~min})$ at $4^{\circ} \mathrm{C}$. The cell pellets were washed and resuspended in $450 \mu \mathrm{L}$ EDTA (100 mmol/L EDTA, $150 \mathrm{mmol} / \mathrm{L}$ $\mathrm{NaCl}, \mathrm{pH}: 8)$. Fifty microliters of lysozyme $(100 \mathrm{mg} / \mathrm{mL})$ were added to the suspension which was incubated in a water bath at $37^{\circ} \mathrm{C}$ for $60 \mathrm{~min}$. After addition of $100 \mu \mathrm{L}$ of $20 \%$ SDS, several extractions were done using chloroform and isoamyl alcohol. DNA was precipitated with ice-cold $70 \%$ ethanol and centrifuged at 13,000 rpm for $5 \mathrm{~min}$. Finally, DNA pellet was dried and then, dissolved in $200 \mu \mathrm{L}$ sterile ultradistilled water containing RNase $(2 \mathrm{~g} / \mathrm{mL})$. DNA isolates were kept at $-20^{\circ} \mathrm{C}$ until use.

Identification of lactic acid bacteria isolates was carried out by partial $16 \mathrm{~S}$ rRNA sequencing of a fragment amplified by PCR using genomic DNA as a template as described by Edwards et al. [1989] including modifications of Beasley et al. [2006] and Benito et al. [2008]. For PCR amplification, DNA was denaturated at $94^{\circ} \mathrm{C}$ for 4 min, cycled 34 times at $94^{\circ} \mathrm{C}$ for $45 \mathrm{~s}, 53^{\circ} \mathrm{C}$ for $1 \mathrm{~min}, 72^{\circ} \mathrm{C}$ for $1 \mathrm{~min}$. Finally a $10 \mathrm{~min}$ extension was done at $72^{\circ} \mathrm{C}$. The primers used for amplification were pAF: 5'-AGA GTT TGA TCC TGG CTC AG-3' and PeR: 5'-CCG TCA ATT CCT TTG AGT TT-3'which hybridizes to the $16 \mathrm{~S}$ rRNA gene at nucleotides (20 bp) 8 to 28 and 928 to 908 in E.coli, respectively. Those universal primers (20 bp) were described in previous reports [Anderson \& McKay, 1983; Beasley et al., 2006]. Amplification products were separated by electrophoresis on $1 \%(\mathrm{w} / \mathrm{v})$ agarose gel containing ethidium bromide at $100 \mathrm{~V}$ for $80 \mathrm{~min}$. PCR products obtained were sequenced at Macrogen Company (www. macrogen.com). BLAST program was used to compare the sequences against the nucleotide database on the NCBI website (http://www.ncbi.nlm.nih.gov/Blast.cgi/).

\section{Genotypic identification of yeasts}

For the genomic DNA extraction, overnight yeast cultures $(5 \mathrm{~mL})$ were harvested by centrifugation $(13,000 \mathrm{rpm}$ for $5 \mathrm{~min})$ at $4^{\circ} \mathrm{C}$. Genomic DNA was isolated by the Instagene Matrix Kit (Bio-Rad, Hercules, CA) as described by the producer. DNA isolates were kept at $-20^{\circ} \mathrm{C}$ until further experiments.

A first differentiation of the yeasts was carried out by the restriction fragment length polymorphism (RFLP) of the 5.8 ITS rRNA gene. This region was amplified following protocol reported by Esteve-Zarzoso et al. [1999]. The DNA fragments were amplified by means of primer ITS1F:5'TCCGTAGGTGAACCTGCGG-3' and ITS4R:5- TCCTCCGCTTATTGATATGC-3'. PCR conditions were $95^{\circ} \mathrm{C}$ for $5 \mathrm{~min} ; 35$ cycles of $94^{\circ} \mathrm{C}$ for $1 \mathrm{~min}, 55^{\circ} \mathrm{C}$ for $2 \mathrm{~min}$, and $72^{\circ} \mathrm{C}$ for $2 \mathrm{~min}$; and finally $10 \mathrm{~min}$ of final extension was done at $72^{\circ} \mathrm{C}$. The DNA fragments subsequently were digested with the endonucleases CfoI, HaeIII and HinfI (Roche Diagnostics, Manheim, Germany) according to the manufacturer's instructions. PCR products and their corresponding restriction fragments were separated in 1.5 and $3 \% \mathrm{w} / \mathrm{v}$ agarose gels, respectively, in 1xTAE $(40 \mathrm{mmol} / \mathrm{L}$ Tris-acetate, $1 \mathrm{mmol} / \mathrm{L}$ EDTA, pH 8.2) buffer. After electrophoresis, the gels were stained with SYBR safe, visualized under UV light and photographed. Sizes were estimated by comparison against a DNA length standard (100 bp ladder, Gibco-BRL). According to band sizes, the groups were formed [Settanni et al., 2011].

One or two samples were chosen from each group and the D1/D2 domains of the 26S rDNA were amplified using primers NL1(5 -GCATATCAATAAGCGGAGGAAAAG-3') and NL4(5 -GGTCCGTGTTTCAAGACGG-3'). PCR conditions were $95^{\circ} \mathrm{C}$ for $5 \mathrm{~min} ; 30$ cycles of $95^{\circ} \mathrm{C}$ for $1 \mathrm{~min}, 52^{\circ} \mathrm{C}$ for $45 \mathrm{sec}$, and $72^{\circ} \mathrm{C}$ for $1 \mathrm{~min}$; and $72^{\circ} \mathrm{C}$ for $7 \mathrm{~min}$. After electrophoresis, they were stained with SYBR safe, visualized under UV light. To determine the closest relatives of $26 \mathrm{~S}$ rDNA sequences, a search of DNA database was conducted by using the BLAST algorithm [Settanni et al., 2011].

\section{Liquid sourdough preparation}

Liquid sourdoughs were obtained using wheat (Triticum aestivum), whole wheat and whole rye (Secala cereale) flours. Flours were purchased from local market. The general composition of wheat flour, whole wheat flour and rye flour were respectively as follows: moisture, 14\%, $13.13 \%$ and $11.96 \%$; protein, $11.70 \%, 13.13 \%$ and $11.96 \%$; ash, $0.68 \%, 1.74 \%$ and $1.66 \%$; falling number, $365 \mathrm{sec}, 318 \mathrm{sec}$ and $271 \mathrm{sec}$.

The inoculum used for liquid sourdoughs was mixed cultures of lactic acid bacteria isolated in the present study at the inoculum level of $10^{9} \mathrm{cfu} / \mathrm{mL}$ per strains and commercial bakers' yeast Saccharomyces cerevisiae inoculated at $10^{7} \mathrm{cfu} / \mathrm{mL}$. Four different starter combinations were used as inoculums. Starter combinations were prepared as follows: S1 L. sanfranciscensis-Pediococcus pentosaceus-L. rosiae-Saccharomyces cerevisiae; S2 L. sanfranciscensis-L. plantarum-L. spicheri-Saccharomyces cerevisiae; S3 Pediococcus pentosaceus-L. zymae-L. namurensis-Saccharomyces cerevisiae; S4 L. plantarum-Leuconostoc mesenterodies-L. casei-Saccharomyces cerevisiae.

Liquid sourdoughs were prepared by mixing flour, tap water and inoculums to obtain dough yields (DY; mass of dough/mass of flour x 100) of 250 and 400 in a total volume of $400 \mathrm{~g}$ in a $500 \mathrm{~mL}$ sterile beaker covered with aluminium foil. Fermentations were started by mixing $240 \mathrm{~g}$ tap water, $160 \mathrm{~g}$ flour and starter for doughs with DY 250, while $300 \mathrm{~g}$ tap water, $100 \mathrm{~g}$ flour and starter for doughs with DY 400 in a sterile beaker. The beakers were put on orbital shaker $(150 \mathrm{rpm})$ to keep the mixture as homogeneous for $4 \mathrm{~d}$ at $30^{\circ} \mathrm{C}$. The back-slopping was made in every $24 \mathrm{~h}$ during $3 \mathrm{~d}$. For back-slopping, $64 \mathrm{~g}$ of ripe sourdough for DY 250 and $40 \mathrm{~g}$ of ripe sourdough for DY 400 were inoculated in a fresh tap water and flour mixture $(135 \mathrm{~g}$ flour and $201 \mathrm{~g}$ tap water for DY 250; $90 \mathrm{~g}$ flour and $270 \mathrm{~g}$ tap water for DY 400) into the sterile beaker. This dough was incubated under the same conditions. Control liquid sourdough was prepared without starter inoculum for each type of flour and dough yield.

\section{Determination of $\mathrm{pH}$, total titratable acidity (TTA), dry matter, sugars, organic acids and ethanol}

Sourdough samples $(10 \mathrm{~g})$ were homogenized with $90 \mathrm{~mL}$ of sterile distilled water using a blender. The $\mathrm{pH}$ value was determined using a $\mathrm{pH}$ meter. TTA was analyzed using $0.1 \mathrm{~N}$ $\mathrm{NaOH}$ to final $\mathrm{pH} 8.5$ and expressed as $\mathrm{mL}$ of $\mathrm{NaOH}$ [Paramithiotis et al., 2006]. Dry matter was determined by heating 
the sample in an oven at $105^{\circ} \mathrm{C}$ until a constant weight was obtained [Gül et al., 2005]. Maltose, glucose, fructose, ethanol, lactic and acetic acids were determined using high performance liquid chromatography (Shimadzu, Kyoto, Japan) with an Aminex HPX-87H column (Biorad, Ricmont, USA) at $35^{\circ} \mathrm{C}$ according to Paramithiotis et al. [2006]. The eluent was $5 \mathrm{mmol} / \mathrm{L} \mathrm{H}_{2} \mathrm{SO}_{4}$ at a flow rate of $0.5 \mathrm{~mL} / \mathrm{min}$. Fructose and mannitol were separated on an Aminex HPX-87C column (Biorad, Ricmont, USA) at $75^{\circ} \mathrm{C}$ at a flow rate of $0.6 \mathrm{~mL} / \mathrm{min}$. The amounts of maltose, glucose, fructose and ethanol were calculated using a refractive index detector and lactic acid and acetic acid using UV detection.

\section{Statistical analyses}

Analyses of variance were performed on the data obtained at different stages of manufacture in accordance with SPSS for Windows, version 7.5. Differences between means were separated using Duncan's multiple range test.

\section{RESULTS AND DISCUSSION}

\section{Physicochemical composition and microbiological characteristics of sourdoughs}

Physicochemical composition of Turkish sourdoughs obtained from several bakeries in different cities of Turkey is given in Table 1.

The levels of $\mathrm{pH}$, TTA and dry matter of sourdoughs differed from sample to sample. Sourdoughs had $\mathrm{pH}$ values ranging from 3.77 to 5.44 . Lower $\mathrm{pH}$ values were found in sourdoughs C, D, E and F, varying between 3.77 and 3.98, whereas sourdough $\mathrm{H}$ was characterized with the highest $\mathrm{pH}$ of 5.44. The others showed $\mathrm{pH}$ levels of $4.02-4.17$. These data were confirmed by TTA that sourdoughs C, D, E, F gave the highest levels of TTA ranging from 10.80 to $14.36 \mathrm{~mL}$ $\mathrm{NaOH}$. However, sourdoughs $\mathrm{G}$ and $\mathrm{H}$ showed higher acidity (14.36 mL NaOH) and lower acidity (4.03 mL NaOH), respectively than other samples. It is well known that during the sourdough fermentation, mostly lactic acid bacteria convert sugars, starting from glucose into the lactic acid and acetic acid, leading to a decrease in $\mathrm{pH}$ and rise in total acidity [Corsetti \& Settanni, 2007]. In the present study, pH and TTA levels are in good agreement with results of Gül et al. [2005] and Şimşek et al. [2006] who studied Turkish sourdoughs and Minervini et al. [2012a] and Lattanzi et al. [2013] who worked on Italian sourdoughs used for bread production. Ercolini et al. [2013] reported higher pH levels and lower TTA in laboratory sourdoughs made from wheat and rye flour after 10 days of propagation. Sourdoughs considered in the present study had dry matter amounts varying from $52.48 \%$ to $60.11 \%$. Gül et al. [2005] reported similar percentages for sourdoughs obtained from different bakeries in Isparta, Turkey; however Şimşek et al. [2006] found slightly lower amounts of the dry matter ranging from $43 \%$ to $50.6 \%$ collected from bakeries in the province of Uşak, Turkey.

Table 1 also shows microbiological characteristics of Turkish sourdoughs. Total mesophilic aerobic bacteria counts of 5.51 to $8.10 \log \mathrm{cfu} / \mathrm{mL}$ were recorded for sourdoughs. These results are within the data given by Şimşek
TABLE 1. Physicochemical composition and microbiological loads of Turkish sourdoughs collected from several provinces and bakeries.

\begin{tabular}{|c|c|c|c|c|c|c|c|c|c|}
\hline 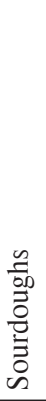 & $\stackrel{\pi}{2}$ & 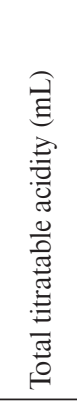 & 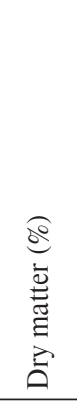 & 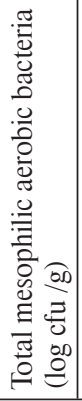 & 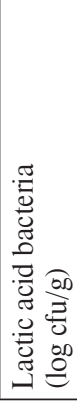 & 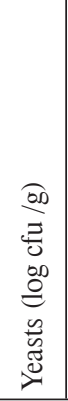 & 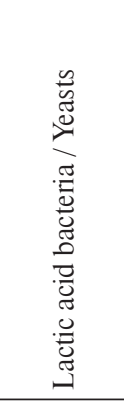 & 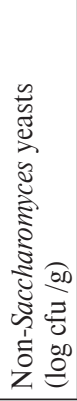 & 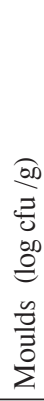 \\
\hline A & 4.17 & 8.35 & 57.32 & 5.51 & 6.71 & 5.27 & $27.54: 1$ & 3.47 & $<1$ \\
\hline B & 4.02 & 9.58 & 53.17 & 5.92 & 7.37 & 5.92 & $28.18: 1$ & 3.56 & $<1$ \\
\hline $\mathrm{C}$ & 3.98 & 14.36 & 58.20 & 7.52 & 9.16 & 7.31 & $70.79: 1$ & $<1$ & $<1$ \\
\hline D & 3.91 & 12.70 & 60.11 & 7.77 & 8.63 & 7.32 & $20.41: 1$ & $<1$ & $<1$ \\
\hline $\mathrm{E}$ & 3.77 & 14.11 & 58.47 & 6.32 & 8.88 & 6.11 & $588.84: 1$ & 2.72 & $<1$ \\
\hline $\mathrm{F}$ & 3.91 & 10.80 & 58.1 & 6.72 & 8.28 & 6.79 & $30.90: 1$ & 2.54 & $<1$ \\
\hline G & 4.04 & 14.42 & 56.73 & 6.70 & 7.85 & 6.68 & $14.79: 1$ & $<1$ & $<1$ \\
\hline $\mathrm{H}$ & 5.44 & 4.03 & 52.48 & 8.10 & 7.26 & 8.08 & $0.15: 1$ & 1.78 & $<1$ \\
\hline
\end{tabular}

et al. [2006] and Gül et al. [2005], i.e. 5.95-7.81 log cfu/mL and 5.97-9.57 log cfu/mL, respectively.

In the present study, cell density of lactic acid bacteria in sourdough $\mathrm{C}$ was the highest of $9.16 \log \mathrm{cfu} / \mathrm{mL}$, whereas sourdough A gave the lowest value of $6.71 \log \mathrm{cfu} / \mathrm{mL}$. Plate counts of lactic acid bacteria in other samples varied between 7.26 and $8.88 \log \mathrm{cfu} / \mathrm{mL}$. Yeast densities ranging from 5.27 to $7.32 \log \mathrm{cfu} / \mathrm{mL}$ in sourdough samples were lower than those of lactic acid bacteria with the exception of sourdough $\mathrm{H}$ which was characterized by an unusual dominance of yeasts $(8.08 \log \mathrm{cfu} / \mathrm{mL})$. The ratio between lactic acid bacteria and yeasts was about in the range of 15:1 - 600.1, with the ratios of 15:1 - 1:70 for most of the sourdough, except sourdough $\mathrm{H}$ having about 1:10 lactic acid bacteria / yeasts ratio (Table 1). Considering the densities of lactic acid bacteria and yeasts here studied match results of data reported by others in the literature [Minervini et al., 2012a; Ercolini et al., 2013; Lattanzi et al., 2013]. Table 1 gives that the counts of non-Saccharomyces yeasts were lower than $3.56 \log \mathrm{cfu} / \mathrm{mL}$ while these of moulds lower than $1 \log \mathrm{cfu} / \mathrm{mL}$.

\section{Identification of dominant lactic acid bacteria and yeasts isolated from sourdoughs}

One hundred and twenty presumptive lactic acid bacteria as being Gram-positive, catalase-negative isolated from the 8 different sourdoughs, included rods or cocci. The isolates were subjected to the partial $16 \mathrm{~S}$ rRNA gene sequencing. 99 isolates showed sequence homology higher than $97 \%$, 15 isolates between $90-96 \%$ and 6 isolates between $85-89 \%$ with those available in public databases. The identification was as follows: $70 \%$ of isolates were Lactobacillus spp., $15.8 \%$ of Pediococcus spp., 9.2\% of Leuconostoc spp., $4.2 \%$ of Enterecocus spp. and $0.8 \%$ of Weisella spp. These results are in agree- 
ment with most of the published papers reporting, Lactobacillus the most frequently identified genus in sourdough while Pediococcus, Leuconostoc, Enterecocus, and Weisella are isolated at a lesser frequency [Corsetti \& Settanni, 2007; De Vuyst et al., 2009; Minervini et al., 2014].

Sourdough samples showed different profile of lactic acid bacteria (Table 2) with most of them belonging to the heterofermentative group as stated in the literature [Corsetti \& Settanni, 2007; De Vuyst et al., 2009]. Although many lactic acid fermented foods are obtained by homofermentative lactic acid bacteria, heterofermentative species play a significant role in sourdough fermentations especially in type I sourdoughs. The species mainly isolated from these sourdoughs are L. sanfranciscensis, (synonym L. brevis var. lindneri), L. plantarum, L. brevis, L. rossiae (formerly L. rossii) and L. paralimentarius [Gobbetti, 1998; Corsetti \& Settanni, 2007; De Vuyst et al., 2009].

In the present study, L. sanfranciscensis (20 isolates) dominated in sourdoughs B and E, whereas L. plantarum (16 isolates) was the dominant species in sourdoughs $C$ and D. Sourdough A harboured two dominant species of $L$. rossiae (6 isolates) and Pediococcus pentosaceus (5 isolates). Pediococcus pentosaceus (6 isolates) and Leuconostoc mesenteroides (9 isolates) were dominant isolates in sourdough H. In turn, L. namurensis (4 isolates) and L. zymae (3 isolates) were detected as dominant species in sourdoughs $\mathrm{F}$ and $\mathrm{G}$. The following species were also found in sourdoughs in the present study: L. spicheri, L. casei, L. mindensis, L. acetotolerans, L. farcimnis, L. paralimentarius, Enterococcus durans, Enterococcus faecium and Weissella confusa. Other studies on Turkish sourdoughs report the most frequently isolated lactic acid bacteria as L. brevis, L. alimentarius and L. plantarum, whereas Carnobacterium divergens (Formerly L. divergens), L. amylophilus, L. sake, L. acetotolerans, L. acidophilus, P. pentosaceus, P. acidilactici and Tetragenococcus halophilus (P. halophilus), $L$. agilis are also detected with lower frequencies [Özcangaz, 2000; Menteş et al., 2004; Gül et al., 2005].

Eighty-two yeast isolates were selected from Turkish sourdoughs and subjected to analysis of 5.8S-ITS region of the rRNA gene and subsequent RFLP-PCR. The first analysis consisting of molecular weight determination of the rRNA region 5.8S ITS generated four products (Table 3). Using the restriction endonucleases $C f o \mathrm{I}, \mathrm{Hae}$ III and HinfI produced four, three and five different profiles, respectively as can be seen in Table 3 .

Different profiles obtained were confirmed by partial sequence analysis of 26S rRNA gene, showing more than $97 \%$ nucleotide sequence identity. Saccharomyces cerevisiae (58 isolates) was the dominant species, identified in all the sourdough samples (Table 2). It is well known that yeasts are present in most sourdoughs and Saccharomyces cerevisiae is the most frequently isolated yeast species from sourdoughs of various countries [i.e. Gül et al., 2005; Valmorri et al., 2010; Minervini et al., 2012a]. As can be seen from Table 2, non-Saccharomyces yeasts were also identified in the present study, depending on sourdough samples. Pichia guilliermondii (14 isolates) was the second frequently isolated species in all sourdoughs with the exception of sourdoughs A and B. Torulaspora delbrueckii (7 isolates), Candida parapsilosis (2 isolates) and Candida
TABLE 2. Dominant species of lactic acid bacteria and yeasts isolated from Turkish sourdoughs obtained from several provinces and bakeries.

\begin{tabular}{|c|c|c|c|c|c|c|c|c|}
\hline \multirow{2}{*}{$\begin{array}{l}\text { Bacterial } \\
\text { species }\end{array}$} & \multicolumn{8}{|c|}{ Sourdoughs } \\
\hline & A & B & $\mathrm{C}$ & $\mathrm{D}$ & E & $\mathrm{F}$ & $\mathrm{G}$ & $\mathrm{H}$ \\
\hline \multicolumn{9}{|c|}{ Lactic acid bacteria } \\
\hline $\begin{array}{l}\text { Lactobacillus } \\
\text { plantarum }\end{array}$ & & $1 / 15$ & $5 / 12$ & $8 / 14$ & $1 / 16$ & & & $1 / 23$ \\
\hline $\begin{array}{l}\text { Lactobacillus } \\
\text { sanfranciscensis }\end{array}$ & & $7 / 15$ & & & $12 / 16$ & $1 / 14$ & & \\
\hline $\begin{array}{l}\text { Lactobacillus } \\
\text { spicheri }\end{array}$ & & $1 / 15$ & $1 / 12$ & & $3 / 16$ & & & \\
\hline $\begin{array}{l}\text { Lactobacillus } \\
\text { rossiae }\end{array}$ & $6 / 11$ & $2 / 15$ & & $1 / 14$ & & & $1 / 15$ & $1 / 23$ \\
\hline $\begin{array}{l}\text { Lactobacillus } \\
\text { namurensis }\end{array}$ & & & $2 / 12$ & & & $6 / 14$ & $4 / 15$ & \\
\hline $\begin{array}{l}\text { Lactobacillus } \\
\text { zymae }\end{array}$ & & & & $1 / 14$ & & $4 / 14$ & $3 / 15$ & \\
\hline $\begin{array}{l}\text { Lactobacillus } \\
\text { casei }\end{array}$ & & & & & & & & $1 / 23$ \\
\hline $\begin{array}{l}\text { Lactobacillus } \\
\text { mindensis }\end{array}$ & & & $1 / 12$ & $1 / 14$ & & $1 / 14$ & & \\
\hline $\begin{array}{l}\text { Lactobacillus } \\
\text { acetotolerans }\end{array}$ & & & & & & & $1 / 15$ & \\
\hline $\begin{array}{l}\text { Lactobacillus } \\
\text { farciminis }\end{array}$ & & & & & & $1 / 14$ & $2 / 15$ & \\
\hline $\begin{array}{l}\text { Lactobacillus } \\
\text { paralimentarius }\end{array}$ & & & $1 / 12$ & & & $1 / 14$ & $2 / 15$ & \\
\hline $\begin{array}{l}\text { Pediococcus } \\
\text { pentosaceus }\end{array}$ & $5 / 11$ & $4 / 15$ & $1 / 12$ & $1 / 14$ & & & $2 / 15$ & $6 / 23$ \\
\hline $\begin{array}{l}\text { Enterococcus } \\
\text { durans }\end{array}$ & & & & & & & & $2 / 23$ \\
\hline $\begin{array}{l}\text { Enterococcus } \\
\text { faecium }\end{array}$ & & & & & & & & $3 / 23$ \\
\hline $\begin{array}{l}\text { Leu conostoc } \\
\text { mesenteroides }\end{array}$ & & & $1 / 12$ & $1 / 14$ & & & & $9 / 23$ \\
\hline $\begin{array}{l}\text { Weissella } \\
\text { confuse }\end{array}$ & & & & $1 / 14$ & & & & \\
\hline \multicolumn{9}{|c|}{ Yeast species } \\
\hline $\begin{array}{l}\text { Saccharomyces } \\
\text { cerevisiae }\end{array}$ & $8 / 10$ & $8 / 10$ & $5 / 6$ & $2 / 5$ & $6 / 10$ & $8 / 11$ & $6 / 11$ & $15 / 19$ \\
\hline $\begin{array}{l}\text { Pichia } \\
\text { guiliermondii }\end{array}$ & & & $1 / 6$ & $1 / 5$ & $2 / 10$ & $3 / 11$ & $5 / 11$ & $2 / 19$ \\
\hline $\begin{array}{l}\text { Torulaspora } \\
\text { delbrueckii }\end{array}$ & $2 / 10$ & $2 / 10$ & & $1 / 5$ & $2 / 10$ & & & \\
\hline $\begin{array}{l}\text { Candida } \\
\text { parapsilosis }\end{array}$ & & & & & & & & $2 / 19$ \\
\hline $\begin{array}{l}\text { Candida } \\
\text { pararugosa }\end{array}$ & & & & $1 / 5$ & & & & \\
\hline
\end{tabular}

pararugosa (1 isolate) were also identified with lower frequencies in sourdoughs. In previous studies [i.e. Valmorri et al., 2010; Minervini et al., 2012a; Lattanzi et al., 2013], Candida milleri, Candida krusei, Torulaspora delbrueckii, Kazachstania barnettii, Kazachstania exigua were identified as co-dominant yeast species in various sourdoughs.

\section{Microbiological and physicochemical characteristics of liquid sourdoughs}

Viable loads of lactic acid bacteria within flours were below $1 \mathrm{log} \mathrm{cfu} / \mathrm{g}$, however viable counts of yeasts within wheat flour, whole wheat flour and rye flour were $2.0 \mathrm{log} \mathrm{cfu} / \mathrm{g}$, 
TABLE 3. Size of the 5.8S ITS profiles and of the restriction fragments of the yeasts isolated from Turkish sourdoughs.

\begin{tabular}{l|c|c|c|c|c}
\hline \multirow{2}{*}{ Species } & \multirow{2}{*}{ ITS (bp) } & \multicolumn{3}{|c|}{ RFLP products (bp) } & Isolation source \\
\cline { 3 - 6 } & & CfoI & HaeIII & HinfI & All sourdoughs \\
\hline Saccharomyces cerevisiae & 880 & $360+350+150$ & $320+240+180+140$ & $380+140+50$ & Sourdoughs \\
Pichiaa guilliermindii & 620 & $300+260+60$ & $410+130+80$ & $300+260+50$ & C,D,E,F,G,H \\
Torulaspora delbrueckii & 820 & $320+230+160+100$ & n.c. & $420+380 /$ & Sourdoughs A, B, D, E \\
Candida parapsilosis & 520 & $300+220$ & 400 & $280+50$ & Sourdough H \\
Candida pararugosa & 420 & $250+170$ & n.c. & $220+200$ & Sourdough D \\
\hline
\end{tabular}

n.c. not cut.

TABLE 4. Counts of lactic acid bacteria and yeasts of liquid sourdoughs.

\begin{tabular}{lcccc}
\hline Sample & & $\begin{array}{c}\text { Lactic acid bacteria } \\
(\log \mathrm{cfu} / \mathrm{g})\end{array}$ & $\begin{array}{c}\text { Yeasts } \\
(\log \mathrm{cfu} / \mathrm{g})\end{array}$ \\
\hline Control & S1 & $9.82 \pm 0.36$ & $6.55^{\mathrm{b}} \pm 0.33$ \\
\hline \multirow{4}{*}{ Starter } & S2 & $9.62 \pm 0.57$ & $7.17^{\mathrm{a}} \pm 0.39$ \\
& S3 & $9.68 \pm 0.53$ & $7.36^{\mathrm{a}} \pm 0.44$ \\
& S4 & $9.61 \pm 0.59$ & $7.29^{\mathrm{a}} \pm 0.56$ \\
\hline \multirow{4}{*}{ Flour } & Sig & n.s. & $*$ \\
& WF & $9.53 \pm 0.45$ & $7.20 \pm 0.57$ \\
& WWF & $9.67 \pm 0.54$ & $7.18 \pm 0.38$ \\
& RF & $9.89 \pm 0.44$ & $7.03 \pm 0.58$ \\
\cline { 2 - 4 } Yield & Sig & n.s. & n.s. \\
\hline \multirow{3}{*}{} & DY 250 & $9.77 \pm 0.44$ & $7.08 \pm 0.52$ \\
& DY 400 & $9.62 \pm 0.53$ & $7.19 \pm 0.51$ \\
\cline { 2 - 4 } & Sig & n.s. & n.s.
\end{tabular}

S1,S2,S3,S4: Abbreviations as given in Material and Methods, WF: Wheat flour, WWF: Whole wheat flour, RF: Rye flour, DY: Dough yield. All determinations were performed in triplicate. Sig: significance, ${ }^{*}$ displays the significance at $5 \%$ by LSD. n.s: Not significant. Values not sharing the same superscript letter within vertical line are different according to Duncan test.

$2.6 \log \mathrm{cfu} / \mathrm{g}$ and $3.3 \log \mathrm{cfu} / \mathrm{g}$, respectively (data not shown). Alfonzo et al. [2013] reported that counts of lactic acid bacteria of wheat flours ranged from $<1 \log \mathrm{cfu} / \mathrm{g}$ to $4.75 \log \mathrm{cfu} / \mathrm{g}$. In the present study, counts of lactic acid bacteria and yeasts were followed during the liquid sourdough fermentations (data not shown). After sourdough fermentations started, lactic acid bacteria and yeasts exhibited maximum growth and lactic acid bacteria counts were between $9.61 \mathrm{log} \mathrm{cfu} / \mathrm{g}$ and $9.89 \mathrm{log} \mathrm{cfu} / \mathrm{g}$ at the end (Table 4). Yeast loads in all samples ranged from $7.03 \mathrm{log} \mathrm{cfu} / \mathrm{g}$ to $7.36 \mathrm{log} \mathrm{cfu} / \mathrm{g}$ with the exception of control sample with $6.55 \mathrm{log} \mathrm{cfu} / \mathrm{g}$.

Physicochemical characteristics of liquid sourdough at the end of fermentation are presented in Table 5. Regarding starter combinations, control sample had the highest concentration of TTA $(13.12 \mathrm{~mL} \mathrm{NaOH})$ and the lowest concentra- tion of TTA was found for $\mathrm{S} 3(11.50 \mathrm{~mL} \mathrm{NaOH})$. There is no significance in terms of $\mathrm{pH}$ values of sourdough samples depending on strain combinations ( $\mathrm{pH}: 3.59-3.64)$ and dough yields $(\mathrm{pH}: 3.56-3.65), \mathrm{pH}$ levels were found in the range of 3.49-3.71 depending on flour type $(\mathrm{p}<0.01)$. After the fermentation, TTA levels increased mainly by the action of lactic acid bacteria, confirming drop in $\mathrm{pH}$ values and TTA amounts significantly differed among liquid sourdoughs $(p<0.01)$. When comparing to starter combinations, acidification of control sourdough was slower by day 1 compared to other starter combinations (data not shown). When fermentations ended, sourdough acidity was higher in the control sample (13.12 $\mathrm{mL} \mathrm{NaOH}$ ), however lower acidity values were obtained with $\mathrm{S} 3$ treatment at the end of fermentation. Liquid sourdough made by WWF gave TTA of $14.08 \mathrm{~mL}$ $\mathrm{NaOH}$, while $9.02 \mathrm{~mL} \mathrm{NaOH}$ of acidity was produced in WF sourdough. Depending on yield, the acidification of the liquid sourdoughs was higher for doughs with DY 250 compared to dough with DY 400 . The results obtained in this study are in agreement with previous studies [Banu \& Aprodu, 2012; Nionelli et al., 2014] reporting that sourdough acidification kinetics are affected by starter, flour type and dough yield.

Lactic acid is the main metabolic end product formed by homofermentative and heterofermentative lactic acid bacteria during sourdough fermentation [Corsetti \& Settanni, 2007; De Vuyst et al., 2009; Minervini et al., 2014]. As reported in Table 5, differences in lactic acid content were observed $(\mathrm{p}<0.01)$. Lactic acid varied from $8.50 \mathrm{~g} / \mathrm{kg}$ to $8.89 \mathrm{~g} / \mathrm{kg}$ with mixed cultures, $5.74-10.46 \mathrm{~g} / \mathrm{kg}$ for flours and $7.32-9.88 \mathrm{~g} / \mathrm{kg}$ for DY. Sourdough samples prepared with rye flour and DY 250 had more lactic acid and the sample made with wheat flour had the lowest lactic acid than the others. These results are similar with previously reported data of $4.18-12.80 \mathrm{~g} / \mathrm{kg}$ lactic acid [Rosenquist \& Hansen, 2000; Paramithiotis et al., 2006; Valmorri et al., 2010; Minervini et al., 2012a], but higher than the results $(2.52-6.93 \mathrm{~g} / \mathrm{kg})$ obtained by De Vuyst et al. [2002] and Vernocchi et al. [2004].

Acetic acid is produced by heterofermantative lactic acid bacteria and also by yeasts [Corsetti \& Settanni, 2007; De Vuyst et al., 2009; Minervini et al., 2014]. Acetic acid was formed in the range of $0.46-0.98 \mathrm{~g} / \mathrm{kg}$, with the highest corresponding to the control sample and lowest with S3 sourdough (Table 5). Its amounts obtained in the present study are in good accordance with results $(0-1.86 \mathrm{~g} / \mathrm{kg})$ reported 
TABLE 5. Physicochemical characteristics of liquid sourdoughs.

\begin{tabular}{|c|c|c|c|c|c|c|c|c|c|c|c|}
\hline Sample & & $\frac{\pi}{2}$ & 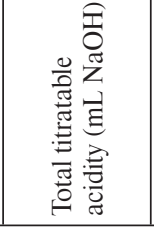 & 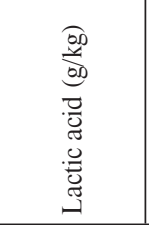 & 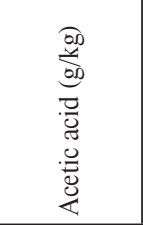 & 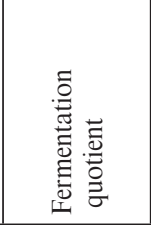 & 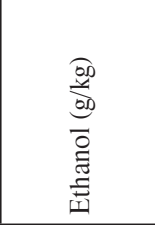 & 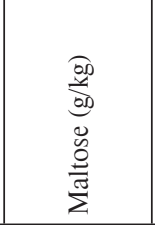 & 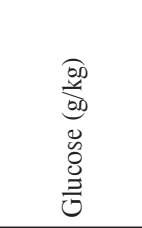 & 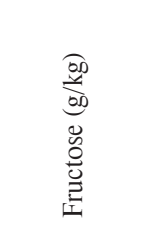 & 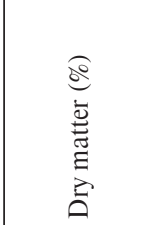 \\
\hline Control & & $3.59 \pm 0.18$ & $13.12^{\mathrm{a}} \pm 3.28$ & $8.89^{\mathrm{a}} \pm 1.74$ & $0.98^{a} \pm 0.35$ & $9.91^{\mathrm{d}} \pm 3.11$ & $10.22^{\mathrm{d}} \pm 5.54$ & $0.07^{\mathrm{a}} \pm 0.07$ & $0.29^{\mathrm{a}} \pm 0.14$ & $0.80^{\mathrm{a}} \pm 0.90$ & $25.95 \pm 7.60$ \\
\hline \multirow{5}{*}{ Starter } & S1 & $3.64 \pm 0.15$ & $12.60^{\mathrm{ab}} \pm 3.5$ & $8.54^{b} \pm 2.53$ & $0.75^{\mathrm{c}} \pm 0.29$ & $12.08^{\mathrm{c}} \pm 3.00$ & $11.23^{\mathrm{bc}} \pm 4.92$ & $0.06^{\mathrm{b}} \pm 0.08$ & $0.22^{\mathrm{b}} \pm 0.06$ & $0.66^{\mathrm{bc}} \pm 0.63$ & $25.93 \pm 8.17$ \\
\hline & S2 & $3.61 \pm 0.12$ & $12.26^{\mathrm{ab}} \pm 2.2$ & $8.47^{b} \pm 2.80$ & $0.93^{\mathrm{b}} \pm 0.18$ & $10.00^{\mathrm{d}} \pm 5.40$ & $10.91^{\mathrm{c}} \pm 4.01$ & $0.02^{\mathrm{c}} \pm 0.05$ & $0.21^{b} \pm 0.07$ & $0.61^{\mathrm{c}} \pm 0.50$ & $26.09 \pm 8.26$ \\
\hline & S3 & $3.60 \pm 0.14$ & $11.50^{b} \pm 3.15$ & $8.50^{\mathrm{b}} \pm 2.84$ & $0.46^{\mathrm{e}} \pm 0.14$ & $18.47^{\mathrm{a}} \pm 2.40$ & $11.63^{\mathrm{b}} \pm 4.82$ & $0.02^{\mathrm{c}} \pm 0.05$ & $0.16^{c} \pm 0.08$ & $0.59^{\mathrm{c}} \pm 0.66$ & $25.91 \pm 7.41$ \\
\hline & S4 & $3.62 \pm 010$ & $11.61^{b} \pm 3.60$ & $8.60^{b} \pm 3.46$ & $0.55^{\mathrm{d}} \pm 0.17$ & $15.56^{b} \pm 4.25$ & $12.30^{\mathrm{a}} \pm 4.76$ & $0.05^{\mathrm{b}} \pm 0.11$ & $0.20^{\mathrm{b}} \pm 0.05$ & $0.69^{b} \pm 0.68$ & $26.63 \pm 6.85$ \\
\hline & Sig & n.s. & *** & *** & ** & *** & $* *$ & ** & ** & $* *$ & n.s. \\
\hline \multirow{4}{*}{ Flour } & WF & $3.49^{\mathrm{c}} \pm 0.10$ & $9.02^{b} \pm 0.98$ & $5.74^{\mathrm{c}} \pm 0.72$ & $0.57^{\mathrm{c}} \pm 0.28$ & $12.44^{b} \pm 5.28$ & $11.43^{\mathrm{b}} \pm 4.80$ & $0.12^{\mathrm{a}} \pm 0.09$ & $0.21^{b} \pm 0.12$ & $0.45^{b} \pm 0.09$ & $24.63^{\mathrm{b}} \pm 6.70$ \\
\hline & WWF & $3.71^{\mathrm{a}} \pm 0.08$ & $14.08^{\mathrm{a}} \pm 2.82$ & $9.60^{\mathrm{b}} \pm 1.91$ & $0.85^{\mathrm{a}} \pm 0.38$ & $13.61^{\mathrm{a}} \pm 5.86$ & $14.47^{\mathrm{a}} \pm 4.12$ & $0.01^{\mathrm{b}} \pm 0.04$ & $0.18^{\mathrm{c}} \pm 0.08$ & $0.05^{\mathrm{c}} \pm 0.07$ & $26.04^{\mathrm{b}} \pm 8.88$ \\
\hline & $\mathrm{RF}$ & $3.64^{b} \pm 0.12$ & $13.56^{\mathrm{a}} \pm 2.84$ & $10.46^{\mathrm{a}} \pm 2.04$ & $0.80^{\mathrm{b}} \pm 0.16$ & $13.57^{\mathrm{a}} \pm 3.67$ & $7.87^{c} \pm 2.49$ & $0.001^{\mathrm{c}} \pm 0.00$ & $0.25^{\mathrm{a}} \pm 0.07$ & $1.51^{\mathrm{a}} \pm 0.39$ & $27.64^{\mathrm{a}} \pm 6.49$ \\
\hline & Sig & ** & *** & *** & *** & *** & $* *$ & ** & *** & ** & $*$ \\
\hline \multirow{3}{*}{ Yield } & DY 250 & $3.65 \pm 0.12$ & $13.93 \pm 3.58$ & $9.88 \pm 2.89$ & $0.72 \pm 025$ & $14.71 \pm 4.30$ & $14.79 \pm 3.66$ & $0.06 \pm 0.09$ & $0.20 \pm 0.09$ & $0.67 \pm 0.69$ & $32.94 \pm 2.39$ \\
\hline & DY 400 & $3.56 \pm 0.14$ & $10.51 \pm 1.74$ & $7.32 \pm 1.55$ & $0.76 \pm 0.36$ & $11.70 \pm 5.20$ & $7.72 \pm 2.46$ & $0.03 \pm 0.06$ & $0.23 \pm 0.10$ & $0.66 \pm 0.64$ & $19.27 \pm 3.08$ \\
\hline & $\mathrm{Sig}$ & *** & *** & *** & $* *$ & ** & $* *$ & ** & $* *$ & $* *$ & ** \\
\hline
\end{tabular}

S1,S2,S3,S4: Abbreviations as given in Material and Methods, 4, WF: Wheat flour, WWF: Whole wheat flour, RF: Rye flour, DY: Dough yield. All determinations were performed in triplicate. ${ }^{* *}$ displays the significance at $1 \%,{ }^{*}$ significance at $5 \%$ by LSD. n.s: Not significant. Values not sharing the same superscript letter within vertical line are different according to Duncan test.

previously [De Vuyst et al., 2002; Paramithiotis et al., 2006; Valmorriet al., 2008; Banu et al., 2011; Minervini et al.,2012a].

The fermentation quotient (FQ) is described as the ratio between amounts of lactic acid and acetic acid. It affects the aroma profile, staling rate and microbial stability of the bread [Banu \& Aprodu, 2012; Settanni et al., 2013]. The lowest FQ ratio was found in control sourdough (9.91) and the highest in S3 sample (18.47) whereas the other sourdoughs had FQ in the range of 10 to 15.56 (Table 4), which is in agreement with Banu \& Aprodu [2012] that reported up to $17.7 \mathrm{FQ}$.

Ethanol is the major end product of yeast metabolism of sugars and also secondary product of heterofermentative lactic acid bacteria metabolism [Paramithiotis et al., 2006]. Ethanol levels were in general lower $(7.72-14.79 \mathrm{~g} / \mathrm{kg})$ than those reported by Paramithiotis et al. [2006], indicating higher ethanol levels (14.26-23.46 g/kg) in mixed culture fermentations of lactic acid bacteria and yeasts. In the present study, liquid sourdoughs showed residual maltose $(0-0.12 \mathrm{~g} / \mathrm{kg})$, glucose $(0.16-0.29 \mathrm{~g} / \mathrm{kg})$ and fructose $(0.05-1.51 \mathrm{~g} / \mathrm{kg})$ and dry matter $(19.27-32 \%)$ at the end of fermentation.

\section{CONCLUSIONS}

One of the aims of this study was to obtain more information about chemical and microbial composition of Turkish sourdoughs. Pediococcus pentosaceus, L. plantarum, L. sanfranciscensis and Leuconostoc mesenteroides were detected as the dominant lactic acid bacteria in Turkish sourdoughs. Various authors have reported that most frequently isolated yeast species from wheat flour sourdough is Saccharomyces cerevisiae. Also, in the present study, Saccharomyces cerevisiae was the predominant yeast species. The $\mathrm{pH}$ value ranged between 3.77 and 5.44, and TTA value ranged between 4.03 and $17.77 \mathrm{~mL} \mathrm{NaOH}$. These data showed that some parameters like bakery environment, sourdough process parameters have an effect on the properties of sourdough.

The other aim of this study was to produce liquid sourdough with different flour type, dough yield and starter cultures determined according to dominant properties in sourdough samples taken from different provinces. The experimental evidence about using mixed starter culture during liquid sourdough production showed that the control sample had the lowest $\mathrm{pH}$ and the highest TTA. It means that the microbial community found in nature of flour and house microbiota could be enough for acidification desired, if the fermentation time is long. However, in liquid sourdough production, great differences appeared in $\mathrm{pH}$ and TTA in the first day of fermentation and the control sample had lower acidification than the mixed starter combinations. Consequently, the industrial liquid sourdough fermentation can be made with specific one or two starter cultures and shorter fermentation time instead of $4 \mathrm{~d}$ with refreshment like our study. Thereby more distinguishing results can be obtained. The flour type and dough yield had an effect on the acidification. The acidification of liquid sourdough produced with DY 250 was higher than 
that obtained with DY 400. The sourdough prepared with rye or whole wheat flours had a stronger acidification than wheat flour. Further studies on this subject have to be carried out for better understanding the relationship between starters, environmental factor and technological application.

\section{ACKNOWLEDGEMENTS}

This work has been funded by a grant from Cukurova University Academic Research Projects Unit (ZF2009D20). The authors also thank Prof. F. Özçelik (Ankara University, Turkey), Assoc. Prof. M.S. Özer (Cukurova University, Turkey) and Prof. H. Özkan (Cukurova University, Turkey) for their kind collaboration.

\section{REFERENCES}

1. Alfonzo A., Ventimiglia G., Corona O., Di Gerlando R., Gaglio R., Francesca N., Moschetti G., Settani L., Diversity and technological potential of lactic acid bacteria of wheat flours. Food Microbiol., 2013, 36, 343-354.

2. Anderson D.G., McKay L.L., Simple and rapid method for isolating large plasmid DNA from lactic streptococci. Appl. Environ. Microbiol., 1983, 46, 549-552.

3. Banu I., Aprodu I., Studies concerning the use of Lactobacillus helveticus and Kluyveromyces marxianus for rye sourdough fermentation. Eur. Food Res. Technol., 2012, 234, 769-777.

4. Banu I., Vasilean I., Aprodu I., Quality evaluation of the sourdough rye breads. The Annals of the University Dumerea de Jos of Galati Fascicle VI-Food Technology, 2011, 35(2), 94-105.

5. Beasley S.S., Manninen T.J.K., Saris P.E.J., Lactic acid bacteria isolated from canine faeces. J. Appl. Microbiol., 2006, 101, 131-138.

6. Benito M.J., Serradilla M.J., Ruiz-Moyano S., Martín A., PérezNevado F., Córdoba M.G., Rapid differentiation of lactic acid bacteria from autochthonous fermentation of Iberian dry-fermented sausages. Meat Sci., 2008, 80,656-661.

7. Carnevali P., Ciati R., Leporati A., Paese M., Liquid sourdough fermentation: Industrial application perspectives. Food Microbiol., 2007, 24, 150-154.

8. Catzeddu P., Mura E., Parente E., Sanna M., Farris G.A., Molecular characterization of lactic acid bacteria from sourdoughs breads produced in Sardinia (Italy) and multivariate statistical analyses of results. Syst. Appl. Microbiol., 2006, 29, 138-144.

9. Corsetti A., Settanni L., Lactobacilli in sourdough fermentation. Food Res. Int., 2007, 40, 539-558.

10. De Los Reyes-Gavilán C.G., Limsowtin G.K.Y., Tailliez P., Sechaud L., Accolas J.P., A Lactobacillus helveticus-specific DNA probe detects restriction fragment length polymorphisms in this species. Appl. Environ. Microbiol., 1992, 58, 3429-3432.

11. De Vuyst L., Schrijvers V., Paramithiotis S., Hoste B., Vancanneyt M., Swings J., Kalantzopoulus G., Tsakalidou E., Messens W., The biodiversity of lactic acid bacteria in Greek traditional wheat sourdoughs is reflected in both composition and metabolite formation. Appl. Environ. Microbiol., 2002, 68, 6059-6069.

12. De Vuyst L., Vrancken G., Ravyts F., Rimaux T., Weckx S., Biodiversity, ecological determinants, and metabolic exploitation of sourdough microbiota. Food Microbiol., 2009, 26, 666-675.
13. Edwards U., Rogall T., Blocker H., Emde M., Böttger E.C., Isolation and direct complete nucleotide determination of entire genes. Characterization of a gene coding for $16 \mathrm{~S}$ ribosomal RNA. Nucleic Acids Res., 1989, 17, 7843-7853.

14. Ercolini D., Pontonio E., De Filippis F., Minervini F., La Storia A., Gobbetti M., Di Cagno R., Microbial ecology dynamics during rye and wheat sourdough preparation. Appl. Environ. Microbiol., 2013, 79, 7827-7836.

15. Esteve-Zarzoso B., Belloch C., Uruburu F., Querol A., Identification of yeasts by RFLP analysis of the 5.8S rRNA gene and the two ribosomal internal transcribed spacers. Int. J. Syst. Bacteriol., 1999, 49, 329-337.

16. Gobbetti M., The Sourdough microflora: Interactions of lactic acid bacteria and yeasts. Trends Food Sci. Technol., 1998, 9, 267-274

17. Gobbetti M., De Angelis M., Corsetti A., Di Cagno R., Biochemistry and physiology of sourdough lactic acid bacteria. Trends Food Sci. Technol., 2005, 16, 57-69.

18. Gül H., Özçelik S., Sağdıç O., Certel M., Sourdough bread production with Lactobacilli and S. cerevisiae isolated from sourdoughs. Process Biochem., 2005, 40, 691-697.

19. Lattanzi A., Minervini F., Di Cagno R., Diviccaro A., Antonielli L., Cardinali G., Cappelle S., De Angelis M., Gobbetti M., The lactic acid bacteria and yeast microbiota of eighteen sourdoughs used for the manufacture of traditional Italian sweet leavened baked goods. Int. J. Food Microbiol., 2013, 163, 71-79.

20. Menteş Ö., Akçelik M., Ercan R., Isolation and identification of Lactobacillus strains from sourdoughs produced in Turkey and their fundamental industrial characteristics. Food (Gida), 2004, 29(5), 347-355 (in Turkish).

21. Meroth C.B., Walter J., Hertel C., Brandt M.J., Hammes W.P., Monitoring the bacterial population dynamics in sourdough fermentation processes by using PCR-Denaturing gradient gel electrophoresis. Appl. Environ. Microbiol., 2003, 69, 475-482.

22. Minervini F., De Angelis M., Di Cagno R., Gobbetti M., Ecological parameters influencing microbial diversity and stability of traditional sourdough. Int. J. Food Microbiol., 2014, 171, 136-146

23. Minervini F., Di Cagno R., Lattanzi A., De Angelis M., Antonielli L., Cardinali G., Cappelle S., Gobbetti M., The lactic acid bacteria and yeast microbiotas of 19 sourdoughs used for the manufacture or traditional/typical Italian breads: Interactions between ingredients and microbial species diversity. Appl. Environ. Microbiol., 2012a, 78, 1251-1264.

24. Minervini F., Lattanzi A., De Angelis M., Di Cagno R., Gobbetti M., Influence of artisan bakery- or laboratory- propagated sourdoughs on the diversity of lactic acid bacterium and yeast microbiotas. Appl. Environ. Microbiol., 2012b, 78, 5328-5340.

25. Nionelli L., Curri N., Curiel J.A., Di Cagno R., Pontonia E., Cavoski I., Gobbetti M., Rizzello C.G., Exploitation of Albanian wheat cultivars: Characterization of the flours and lactic acid bacteria microbiota, and selection of starters for sourdough fermentation. Food Microbiol., 2014, 44, 96-107.

26. Özcangaz Ç., Characterization of Lactic Isolates from Turkish Sourdough and Interactions with Yeast, Master of Science, Department of Biotechnology, The Middle East Technical University, 2000, Ankara, p. 101. 
27. Paramithiotis S., Gioulatos S., Tsakalidou E., Kalantzopoulos G., Interactions between Saccharomyces cerevisiae and lactic acid bacteria in sourdough. Process Biochem., 2006, 41, 2429-2433.

28. Ravyts F., De Vuyst L., Prevalence and impact of single-strain starter cultures of lactic acid bacteria on metabolite formation in sourdough. Food Microbiol., 2011, 28, 1129-1139.

29. Rollàn G., Gerez C.L., Dallgnol A.M., Torino M.I., Font G., Update in bread fermentation by lactic acid bacteria. 2010, in: Current Research, Technology and Education Topics in Applied Microbiology and Microbial Biotechnology (ed. A. Méndez-Vilas). Formatex Research Center, pp. 1168-1174.

30. Rosenquist H., Hansen A., The microbial stability of two bakery sourdoughs made from conventionally and organically grown rye. Food Microbiol., 2000, 17, 241-250.

31. Salin-ur-Rehman, Paterson A., Piggott J.R., Flavour in sourdough breads: A review. Food Sci. Technol., 2006, 17, 557-566.

32. Scheirlinck I., Van Der Meulen R., De Vuyst L., Vandamme P., Huys G., Molecular source tracking of predominant lactic acid bacteria in traditional Belgian sourdoughs and their production environments. J. Appl. Microbiol., 2009, 106, 1081-1092.

33. Scheirlinck I., Van Der Meulen R., Van Schoor A., Cleenwerck I., Huys G., Vandamme P., De Vuyst L., Vancanneyt M., Lactobacillus namurensis sp. nov., isolated from a traditional Belgian sourdough. Int. J. Syst. Evol. Microbiol., 2007, 57, 223-227.

34. Settanni L., Tanguler H., Moschetti G., Reale S., Gargano V., Erten H., Evolution of fermenting microbiota in tarhana produced under controlled technological conditions. Food Microbiol., 2011, 28, 1367-1373.

35. Settanni L., Ventimiglia G., Alfonzo A., Corona O., Miceli A., Moschetti G., An integrated technological approach to the selection of lactic acid bacteria of flour origin for sourdough production. Food Res. Int., 2013, 54, 1569-1578.
36. Şimşek Ö., Çon A.H., Tulumoğlu Ş., Isolating lactic starter cultures with antimicrobial activity for sourdough processes. Food Contr., 2006, 17, 263-270.

37. Valmorri S., Mortensen H.D., Jespersen L., Cosetti A., Gardini F., Suzzi G., Arneborg N., Variations of internal pH in typical Italian sourdough yeasts during co-fermentation with Lactobacilli. LWT-Food Sci. Technol., 2008, 41, 1610-1615.

38. Valmorri S., Tofalo R., Settanni L., Corsetti A., Suzzi G., Yeast microbiota associated with spontaneous sourdough fermentations in the production of traditional wheat sourdough breads of the Abruzzo Region (Italy). Antonie van Leeuwenhoek, 2010, 97, 119-129.

39. Vera A., Rigobello V., Demarigny Y., Comparative study of culture media used for sourdough lactobacilli. Food Microbiol., 2009, 26, 728-733.

40. Vernocchi P., Valmorri S., Dalai I., Torriani S., Gianotti A., Suzzi G., Guerzoni M.E., Mastrocola D., Gardini F., Characterization of the yeast population involved in the production of a typical Italian bread. J. Food Sci., 2004, 69, 182-186.

41. Vogelmann S.A., Seitter M., Singer U., Brandt M.J., Hertel C., Adaptability of lactic acid bacteria and yeasts to sourdoughs prepared from cereals, pseudocereals and cassava and use of competitive strains as starters. Int. J. Food Microbiol., 2009, 130, 205-212.

42. Zannini E., Gaarofalo C., Aquilanti L., Santarelli S., Silvestri G., Clementi F., Microbiological and technological characterization of sourdoughs destined for bread-making with barley flour. Food Microbiol., 2009, 26, 744-753.

Submitted: 8 May 2015. Revised: 15 June 2015. Accepted: 29 June 2015. Published on-line: 31 March 2016. 
